\title{
20
}

\section{Non-Mainstream Media Coverage}

\section{Peter Chen}

From a media diversity perspective, Australia's standing as an established democracy is not strong. When compared with peer democracies, Australia has the most concentrated media system in the world (Australian Collaboration 2015). The causes of this are various, but include comparatively small market size, 'dumping' of English-language content into the Australian market and lacklustre media policy that has facilitated media conglomerates to consolidate their market share (Winseck 2008). As part of this story, the popularisation of the internet over the last two decades has been an exacerbating factor and corrective: undermining the economic basis of established commercial media and eroding domestic regulatory capacity, while at the same time providing the capacity for the establishment of 'new presses'.

This chapter focuses on the conduct and performance of these 'new presses' in the 2016 federal election campaign. While the majority of these new media groups happens to be an internet-based press, the emphasis of this chapter is not on the technological basis of supply per se, but on their relative newness into the Australia marketplace. This breaks with a traditional tendency to see 'new media' as internet-based media, an increasingly meaningless classification tool given the increasing incorporation of new technology into the established media, as discussed by Andrea Carson and Brian McNair (Chapter 19, this volume). 


\section{Method}

The primary research method employed for this chapter is the content analysis of articles published in 10 'new' Australian-based ${ }^{1}$ publicationseach less than seven years old ${ }^{2}$ - that published material during the formal election period from 8 May to 1 July 2016 inclusive. The selection was purposive, with the objective of obtaining a mix of publications, as well as publications with key differences to established media organisations. ${ }^{3}$ The population was defined as all articles published about the election (using the widest interpretation of this class). Given the wide variation of output, articles were sampled randomly from each selected publication (minimum of one per day and maximum of one quarter of total output).

The selected publications are listed in Table 20.1, which includes a brief description of the publication, the number of sampled articles and the publications' Alexa ranks for the Australian market. Alexa is an online web traffic metrics company that collects browsing data to estimate traffic flows to websites and, while having limitations in its accuracy (Kamerer 2013), provides a useful standardised measure of comparison for websites. To facilitate this comparison, a number of high-profile Australian mainstream news media websites are included in the table.

Table 20.1. Sample and comparator publications

\begin{tabular}{|l|l|r|r|}
\hline Publication & Description & $\mathrm{n}$ & $\begin{array}{c}\text { Alexa } \\
\text { rank }\end{array}$ \\
\hline abc.net.au* & $\begin{array}{l}\text { Australian Broadcasting Corporation } \\
\text { website }\end{array}$ & - & 15 \\
\hline news.com.au* & News Corp website & - & 19 \\
\hline smh.com.au* & Sydney Morning Herald website & - & 25 \\
\hline theguardian.com & $\begin{array}{l}\text { Established in 2013, the Guardian } \\
\text { Australia website }\end{array}$ & 541 & 55 \\
\hline BuzzFeed Australia & Established in 2014, a soft-news website & 46 & 85 \\
\hline theaustralian.com.au* & The Australian website & - & 108 \\
\hline dailytelegraph.com.au* & Daily Telegraph website & - & 125 \\
\hline
\end{tabular}

1 In that the publications have Australian staff and offices, even if they also syndicate content from 'parent' publications (e.g. the Guardian, Buzzfeed, etc.).

2 New Matilda has a longer lineage, but was included in the sample because it significantly changed its focus following its separation from the Centre for Policy Development.

3 Particularly those with a youth focus. As Sally Young (2011: 57-58) observes, the websites of established newspapers tend to attract an older audience (average age in the early 60s). 


\begin{tabular}{|l|l|r|r|}
\hline Publication & Description & $\mathrm{n}$ & $\begin{array}{c}\text { Alexa } \\
\text { rank }\end{array}$ \\
\hline Vice Au/NZ & $\begin{array}{l}\text { Established in 2014, a youth-oriented } \\
\text { online magazine }\end{array}$ & 15 & 171 \\
\hline Huffington Post (Au) & $\begin{array}{l}\text { Established in 2015, Australian version } \\
\text { of the blog site }\end{array}$ & 71 & 220 \\
\hline The Conversation (Au) & $\begin{array}{l}\text { Established in 2011, non-profit academic } \\
\text { writing }\end{array}$ & 56 & 670 \\
\hline New Daily & $\begin{array}{l}\text { Established in 2013 as an online-only } \\
\text { newspaper }\end{array}$ & 17 & 1,014 \\
\hline Junkee & $\begin{array}{l}\text { Established in 2013, a youth-oriented } \\
\text { online magazine }\end{array}$ & 8 & 1,733 \\
\hline New Matilda & $\begin{array}{l}\text { In current form, stand-alone magazine } \\
\text { from 2010 }\end{array}$ & 6 & 4,116 \\
\hline The Saturday Paper & $\begin{array}{l}\text { Established in 2014, a weekly news } \\
\text { magazine }\end{array}$ & 364 & $\begin{array}{l}8,389 \\
(58)\end{array}$ \\
\hline Independent Australia & $\begin{array}{l}\text { Established in 2010 with a focus on long- } \\
\text { form writing }\end{array}$ & 29 \\
\hline Total / avg. sample (avg. comparator) &
\end{tabular}

\footnotetext{
* Denotes comparator

${ }^{1}$ Note that the Guardian produced the most context in the sampled publication set Source. Constructed by author from analysis based on content coding from selected publications (8 May to 1 July 2016 inclusive).
}

Table 20.1 shows:

- The quantum of published material on the election during the electoral period is variable across the sample.

- While higher levels of published electoral political material tend to be correlated with the pretentions/reputation of the publication in question (towards more serious news reporting), this is not universal by the focus of the masthead (for example, BuzzFeed, with a dedicated Australian political news editor, is a high producer of content). Additionally, some publications are only modest in their overall production of content (i.e. New Matilda).

- The sample, as would be expected with the focus on comparatively new entrants into the Australian news market, ranks far lower down the Alexa index than the websites of their established media brands, with considerable variability in their popularity. 
- Those publications within this sample that rank comparatively highly are those with international parent companies, most notably the Guardian Australia, having a long publication history in the United Kingdom (but also including the comparatively newer BuzzFeed (USA), Vice (Canada), Huffington Post (USA)).

A mixed-coding process was used including the capture of both manifest (explicit) and latent (implicit/interpretative) elements. These were divided into descriptive data on the presentation of the published material (format), as well as the classification of reported content. The total sample contained an estimated 337,081 words. ${ }^{4}$

In addition, information was requested from a number of editors of the publications analysed in the content analysis.

\section{Description of articles}

The following two tables provide a description of the material produced by the sampled publications during the election campaign. In Table 20.2, we can see the average length of the sampled articles produced. In keeping with the general orientation of the respective mastheads, magazinestyle publications tend to produce longer articles on average than their 'newspaper' and blog-style equivalents. While a number of sampled publications produced fewer articles overall, there is a recognisable negative correlation between the average length of published material and the total number of articles produced during the election periods $(-0.62)$; indicating that the differences in attention paid to the election by the sampled publications is lower than the number of individual articles produced would indicate. In addition, length variability is more likely in magazine and blog-style publications than those more specifically emulating newspaper forms of reporting. ${ }^{5}$

4 A direct count of text. Video- and audio-only content was tabulated at the standard rate of 130 words per minute.

5 The use of live blogging of political events, seen in established newspapers online, and by the Guardian in this sample, is a variation from this. This form of reporting in real time is an innovation in this federal election cycle, and reflects the capacity of media organisations with larger staff to showcase their capacity to cover longer events in detail. 
Table 20.2 Length of sampled articles

\begin{tabular}{|l|r|r|r|r|}
\hline Publication & $\mathrm{n}$ & $\begin{array}{c}\text { Sampled } \\
\text { words }\end{array}$ & \multicolumn{1}{c|}{ Average } & \multicolumn{1}{c|}{ St. Dev. } \\
\hline New Matilda & $8^{1}$ & 19,176 & 2,397 & 1,281 \\
\hline Independent Australia & 29 & 52,756 & 1,819 & 3,558 \\
\hline Vice Au/NZ & 15 & 17,022 & 1,134 & 1,338 \\
\hline The Conversation & 66 & 73,469 & 1,113 & 760 \\
\hline Guardian Australia & 54 & 53,576 & 992 & 853 \\
\hline Junkee & 17 & 11,795 & 693 & 512 \\
\hline Huffington Post & 71 & 43,774 & 616 & 406 \\
\hline BuzzFeed Australia & 46 & 27,091 & 588 & 471 \\
\hline New Daily & 52 & 28,203 & 542 & 245 \\
\hline Saturday Paper & 6 & 10,219 & 1,703 & 339 \\
\hline All & 364 & 337,081 & 926 & 1,247 \\
\hline
\end{tabular}

${ }^{1}$ New Matilda reports it did not increase its allocation of resources to political coverage during the election period (personal correspondence, Chris Graham, publisher/editor, New Matilda, 8 August 2016)

Source. Constructed by author from analysis based on content coding from selected publications (8 May to 1 July 2016 inclusive).

Turning from length to non-textual content, Table 20.3 provides a statistical description of the non-textual elements within articles (or as indicated by 'only' where the articles were audio or video only). Summarising this table, we can see that:

- The most commonly included non-textual elements tend towards material comparatively easily collected as embedded in the text. In order: photographs (almost universally), embedded tweets (or like content, such as Instagram posts) and embedded video content.

- While some of the most common content was unique to the publications, the majority of this was repurposed content. Stock photographs (of the human subjects of the articles in particular) were very common, the exception being the Guardian Australia, which has their own photographic staff. Video content was predominantly news material from other media channels (see below) or party/ candidate materials (election ads). Tweets tended to divide between the observations of elites (candidates, media workers) and content from the general community. The use of tweeted content, it appears, is related to the decline in the use of 'vox pop' material (only 2.7 per cent of articles included collected observations or quotes from 'ordinary voters' worked into article text). 
- Very little of the embedded non-textual material could be described as complex additions to journalistic practice requiring the generation of non-textual material. Of this category, infographics ('visual representations of data or information'; Krum 2014) were the most common and tended to be most likely employed by The Conversation and similar long-form magazine-style publications, while the use of embedded polling or data journalism (use of large data sets to elaborate or form news stories, with or without the inclusion of interactive data in the article; Gray, Chambers and Bounegru 2012: 2-3) was minimal in the sample.

- A small number of articles took the form of unique audio or video, largely interviews or panels of journalists rather than in-field reporting. The use of this type of material was spread across different types of publication.

Table 20.3. Media content of sampled articles (percentage)

\begin{tabular}{|l|r|r|r|r|r|r|r|r|}
\hline Publication & Photo & $\begin{array}{c}\text { Embed } \\
\text { Tweet }\end{array}$ & Video & $\begin{array}{c}\text { Info- } \\
\text { graphic }\end{array}$ & Poll & $\begin{array}{c}\text { Embed } \\
\text { Data }\end{array}$ & $\begin{array}{c}\text { Video } \\
\text { Only }\end{array}$ & $\begin{array}{c}\text { Audio } \\
\text { Only }\end{array}$ \\
\hline BuzzFeed & 96 & 37 & 20 & 11 & 2 & 0 & 0 & 4 \\
\hline The Conversation & 92 & 5 & 5 & 21 & 0 & 0 & 6 & 2 \\
\hline Guardian & 96 & 22 & 15 & 6 & 0 & 0 & 0 & 0 \\
\hline Huffington Post & 93 & 62 & 39 & 4 & 0 & 0 & 0 & 3 \\
\hline $\begin{array}{l}\text { Independent } \\
\text { Australia }\end{array}$ & 100 & 86 & 48 & 10 & 0 & 0 & 0 & 0 \\
\hline Junkee & 100 & 77 & 77 & 0 & 0 & 0 & 0 & 0 \\
\hline New Daily & 100 & 0 & 12 & 2 & 0 & 2 & 0 & 0 \\
\hline New Matilda & 100 & 0 & 13 & 13 & 0 & 0 & 0 & 0 \\
\hline Saturday Paper & 83 & 0 & 0 & 0 & 0 & 0 & 0 & 0 \\
\hline Vice & 80 & 6.7 & 27 & 7 & 0 & 0 & 0 & 20 \\
\hline All & 95 & 32 & 27 & 9 & 0 & 0 & 2 & 1 \\
\hline
\end{tabular}

Source. Constructed by author from analysis based on content coding from selected publications (8 May to 1 July 2016 inclusive).

In summary, while the sample included some variation in the presentation of content, the degree to which these new presses produced forms of electoral coverage that could be seen as significantly different in form to that of established presses was small. 


\section{Coverage of issues and topics}

Moving from form to content, in the following three sections I examine the substance of the material analysed. This analysis has three components: the comparative value of material produced in informing the readers-aselectorate, the coverage of specific issues and policy areas.

Turning first to the question of value, the content analysis of articles sorted them into three categories: 'hard' content, 'soft' content and content with a significant mix of both. This classification process employed Lance Bennett's (2012: 24-32) relatively subjective delineation between 'hard' (information content the knowledge of which defines-through social construction - what an 'informed' person should know at any particular time) and 'soft' (emotional and immediate, entertainment-oriented information). In this classification process, an archetypal 'hard' article can be characterised as one that focused on the reporting of events or issues using the passive voice, an emphasis on facts over interpretation and without humour. 'Soft' articles tended towards more informal language, inclusion of slang and humour, with a higher tendency for editorialisation by the author. ${ }^{6}$

While debate continues about the value of 'soft' news in informing citizens, framing issues and agenda setting, it appears that the presence of 'soft' news can expand awareness of issues outside of core media audiences, particularly amongst traditionally disengaged audiences (Baum 2011: 5-8). What we can see in Figure 20.1 is that the new presses are quite mixed in the nature of their election coverage. This includes publications producing consistently 'hard' content who target more affluent and educated audiences-for example, The Conversation, the Guardian Australia, Independent Australia and the Saturday Paper (Roy Morgan Research 2014) ${ }^{7}$ - than those focusing on casual news consumers (the New Daily, Huffington Post) and youth-oriented publications (BuzzFeed, Junkee and Vice) that are most likely to contain mixed and soft news content. The interesting outlier here is New Matilda, which appears to have a house style that emphasises a wryer tone than its traditional audience would suggest.

6 In extremis, this is pure whimsy, such as the article that comprised solely of a video montage (to music) of the Prime Minister's hand movements while speaking at campaign and media events.

7 The 2016 election saw a considerable disappearance of 'fact check' articles from the media landscape. First introduced in advance of the 2013 federal campaign from a genre pioneered in the United States, only The Conversation used this format in the sample for 4.5 per cent of its election articles. 


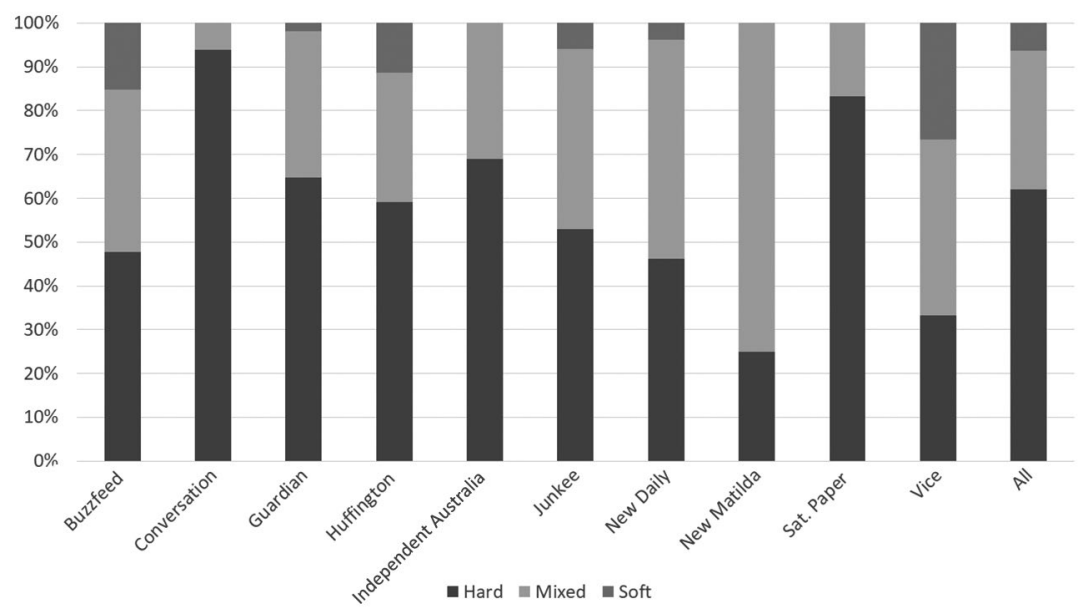

Figure 20.1. Characterisation of reporting, by publication

Source. Constructed by author from analysis based on content coding from selected publications (8 May to 1 July 2016 inclusive).

Examining the substantive issues and policies discussed in the articles sampled is a more complex task, with 252 separate issue topics and policy areas discussed within the 364 articles analysed. The discussion of policy topics, often seen as an exemplar of quality reporting during elections, needs clarification in reporting on the sampled articles. While the total sample included articles with a detailed focus on policy topics, many policy references identified contained little substantive content, such as articles that listed topics discussed by a candidate or at an event without articulating the subject matter of the issue or policy proposal. Thus, using Table 20.4, we can rank publications by the tendency to discuss policy areas in greater detail. Those publications most likely to discuss policy in some detail tended to be independent long-form magazine-style publications (Saturday Paper, Independent Australia and New Matilda). Interestingly, youth publications (Junkee and Vice) also tended to dedicate their (shorter) articles to single policy topics, rather than omnibus reports.

The position of The Conversation in Table 20.4 is interesting, in that its primary focus on analysis by academics is associated with more in-depth coverage on policy topics. This figure would be 4.2 per 1,000 words if we excluded the high number of articles published by Michelle Grattan in The Conversation during the campaign. Grattan, a professorial fellow at the University of Canberra, was recruited to the publication in 2013, and provides material more akin to conventional political journalism (with lower levels of policy analysis) than the contributions of other academics. 
In the 2016 sample, Grattan authored 31.8 per cent of The Conversation's election output. The Conversation is not unique amongst the wholly new publications sampled in adding an established political journalist from traditional media to its ranks, with the New Daily also recruiting longstanding $\mathrm{ABC}$ journalist Kerry O’Brien.

Table 20.4. Policy detail in sampled articles, average

\begin{tabular}{|l|r|}
\hline Publication & Policy topics per 1,000 words \\
\hline BuzzFeed & 7.5 \\
\hline New Daily & 7.4 \\
\hline All & 5.4 \\
\hline Huffington Post & 5.4 \\
\hline The Conversation & 5.3 \\
\hline Vice & 4.6 \\
\hline Guardian & 4.4 \\
\hline Junkee & 4.4 \\
\hline Independent Australia & 3.8 \\
\hline New Matila & 3.5 \\
\hline Saturday Paper & 2.2 \\
\hline
\end{tabular}

Source. Constructed by author from analysis based on content coding from selected publications (8 May to 1 July 2016 inclusive).

To simplify the discussion of these issues and policy topics, I examine areas of commonality and difference in the sample. Tables 20.5 and 20.6 show the most commonly discussed topics (subject areas) and policy issues during the election campaign within the total sample. Key topic themes were:

- Topics associated with the practicalities of the campaign process (campaigning activity itself, polling, gaffes or perceived misconduct of candidates, ${ }^{8}$ marginal seats, party unity and voting behaviour). The New Daily, with a greater focus on traditional newspaper-type reporting, was most likely to focus on campaigning issues than the overall sample.

8 In this regard, the media outlets predominantly focused on three Victorian candidates: for Batman, David Feeney (ALP) who failed to declare the ownership of property; for McEwen, Chris Jermyn (Liberal) who attempted to 'gatecrash' a press conference of the opposition leader unsuccessfully; and, for Calwell, John Min-Chiang Hsu (Liberal) over his ownership of a legal brothel. 
- Demographic groups: women, Aboriginal and Torres Strait Islanders, LGBTI people and youth. Reflecting the tendency for younger people to be more highly engaged with issues associated with samesex marriage, youth-focused publications (BuzzFeed, Junkee and Vice ranked LGBTI issues more prominently than the overall sample).

The interesting outlier in this set is the inclusion of discussions of artistic practice (as opposed to arts policy), which appears at the bottom of the top third list of policy topics. The most common reference in this set was the Sydney-based artist Michael Agzarian, who is notable for his parody Obama-style posters of Australian political elites.

Following on the back of the Budget, issues of the substance of the budget and national budgetary management (including public debt and revenue) dominated the policy topics discussed. Beyond major policy areas common to most elections - the national economy, education and health-three areas of specific focus tended to also be significant in the sampled publications' news agendas:

- Australia's system of offshore asylum seeker detention (see Dehm and Walden, Chapter 26, this volume). ${ }^{9}$

- Medicare, following the emphasis of the ALP in raising Medicare privatisation as a key theme in the second half of the campaign (see Manwaring, Chapter 11; Elliot and Manwaring, Chapter 24, this volume).

- Climate change and the health of the Great Barrier Reef as the specific and dominant focus of the election on environmental issues, rather than broader issues about the environment (this conforms with the observations by Pearse, Chapter 25, this volume). This latter focus is significant given the extremely limited coverage given to the environment in the 2013 federal election (Lester, McGaurr and Tranter 2015).

The alignment of this news agenda with the public agenda is illustrated in Table 20.6 with the inclusion of polling data ('March Poll'). From polling undertaken by the Essential Media Communications group, asking respondents to nominate three issues of most importance to them in the coming election, this column indicates the relative importance of issues where they were included in the poll.

9 At the start of the election period this was commonly associated with the topic of party unity in the ALP (candidates 'breaking ranks' over ALP policy). In the second half of the election period this was more commonly associated with references to the Australian Greens. 
Table 20.5. Top 15 topics, all publications

\begin{tabular}{|l|l|r|}
\hline Rank & Topic & Topic (percentage) \\
\hline 1 & Campaigning & 40.1 \\
\hline 2 & Polling & 17 \\
\hline 3 & Social media & 15.1 \\
\hline 4 & Post-election & 11.3 \\
\hline 5 & Indigenous people & 8.8 \\
\hline 6 & Women & 8.5 \\
\hline 7 & Art & 8.2 \\
\hline 8 & Scandal/embarrass & 8.2 \\
\hline 9 & Marginal seats & 7.7 \\
\hline 10 & Parliament & 7.7 \\
\hline 11 & Leadership & 7.1 \\
\hline 12 & Debate & 5.2 \\
\hline 13 & LGBTI people & 5.2 \\
\hline 14 & Youth & 5.2 \\
\hline 15 & Leaders debate & 4.9 \\
\hline
\end{tabular}

Source. Constructed by author from analysis based on content coding from selected publications (8 May to 1 July 2016 inclusive).

Table 20.6. Policy issues, all publications

\begin{tabular}{|l|l|r|r|}
\hline Rank & Policy & $\begin{array}{c}\text { Policy area (percentage } \\
\text { of coverage) }\end{array}$ & $\begin{array}{c}\text { March Poll* (importance } \\
\text { of issues, percentage) }\end{array}$ \\
\hline 1 & Budget(ary) management & 25.3 & - \\
\hline 2 & Taxation & 24.5 & 29 \\
\hline 3 & Economy & 17.6 & 37 \\
\hline 4 & Asylum seekers/detention & 16.5 & 7 \\
\hline 5 & Education & 14.6 & 21 \\
\hline 6 & Healthcare & 14 & 43 \\
\hline 7 & Climate change & 11.3 & 12 \\
\hline 8 & Same-sex marriage & 10.7 & - \\
\hline 9 & Environment & 10.2 & - \\
\hline 10 & Medicare (specifically) & 9.1 & - \\
\hline 11 & (Un)employment & 8.2 & - \\
\hline 12 & Telecommunications & 8 & - \\
\hline 13 & Great Barrier Reef & 6.6 & 8 \\
\hline 14 & Industrial relations & 6.3 & - \\
\hline 15 & Mining & 5.5 & \\
\hline
\end{tabular}

* From Essential Media Communications (2016)

Source. Constructed by author from analysis based on content coding from selected publications (8 May to 1 July 2016 inclusive). 
The focus on topics and policy issues illustrated in Table 20.6 represents the overarching news agenda of the sampled publications. However, it is useful to highlight key variations within the sample. To do this, we have constructed Figure 20.2. This figure compares the 20 most common topics and 20 most common policy issues of each publication against the aggregated total — the 'median news agenda' (adjusted for each sampled publication's $\mathrm{n}$ ). The figure shows that The Conversation, Huffington Post and the Guardian are closest to the median news agenda, which may be unsurprising given the law of large numbers (they produced the largest number of articles). Alternatively, the most atypical news agenda was perused by an eclectic group of publications: Junkee, Independent Australia and the Saturday Paper.

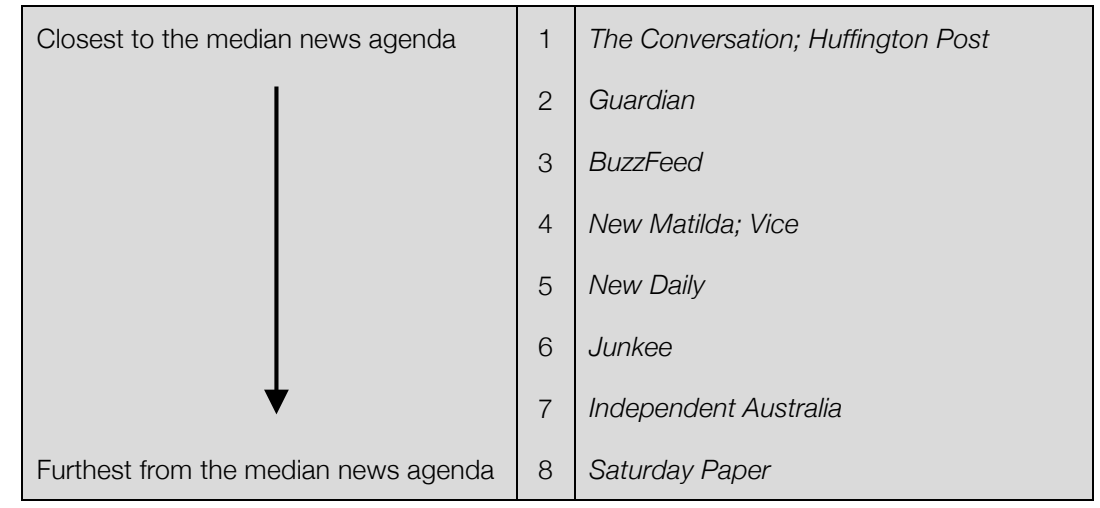

Figure 20.2. Publications' relationship with the median news agenda Source. Constructed by author from analysis based on content coding from selected publications (8 May to 1 July 2016 inclusive).

Each of the three outliers can be explained due to their audience characteristics and ethos-Junkee, for example, focuses on youth popular culture (Robin 2014). Independent Australia, similarly, has a tradition of following issues often neglected by mainstream coverage, while the Saturday Paper's weekly long-form reporting requires it to be outside of the media news cycle.

\section{Coverage of individuals and organisations}

While the sampled publications reported on a large number of individual people (736 unique individuals) and organisations (527 unique organisations) during the campaign, the focus of reporting was far narrower: the two major party leaders dominated references, as did the three established 
parliamentary party groupings. This is illustrated in Table 20.7. The key individuals discussed tended to be party leaders, (shadow) treasurers and individuals holding key portfolios associated with policy topics of interest (as identified above). Outside of this, Nick Xenophon's perceived likelihood of securing a strong result in the Senate led to him and his team being highly ranked, but the sampled media did not pick up on the return of Pauline Hanson and the remarkable Senate successes of Pauline Hanson's One Nation (see Kefford, Chapter 15, this volume).

By and large, reporting on individuals tended to follow the propensity of online publications-as previously observed by Murray Goot (2008: 102) - to focus on a small group of mainstream political actors. However, between the 2007 election analysed by Goot and 2016, we see:

- an increased representation of Greens candidates in the sampled articles

- interestingly, of the top 15 people discussed in the articles sampled, four (26.6 per cent) are former prime ministers no longer seeking public office.

Table 20.7. Names and organisations mentioned in sampled articles

\begin{tabular}{|l|l|r|l|r|}
\hline Rank & Name & Percentage & Organisation & Percentage \\
\hline 1 & Malcolm Turnbull & 53.0 & Coalition/(Nationals) & $68.1 /(10.2)$ \\
\hline 2 & Bill Shorten & 42.3 & Australian Labor Party & 60.4 \\
\hline 3 & Tony Abbott & 25.3 & Australian Greens & 29.7 \\
\hline 4 & Scott Morrison & 13.5 & ABC & 16.2 \\
\hline 5 & Julia Gillard & 12.1 & Q\&A (ABC Television) & 8.5 \\
\hline 6 & Kevin Rudd & 8.5 & Nick Xenophon Team & 7.1 \\
\hline 7 & John Howard & 8.0 & Sky News & 5.5 \\
\hline 8 & Peter Dutton & 7.1 & Australian & 5.2 \\
\hline 9 & Nick Xenophon & 6.3 & News Corporation & 4.9 \\
\hline 10 & Chris Bowen & 6.0 & Australian Electoral & 4.1 \\
\hline 11 & Richard Di Natale & 5.5 & Fairfax & 3.3 \\
\hline 12 & Paul Keating & 4.9 & GetUp! & 3 \\
\hline 13 & Julie Bishop & 4.7 & National Press Club & 3 \\
\hline 14 & Mathias Cormann & 4.4 & Newspoll & 3 \\
\hline 15 & Pauline Hanson & 4.4 & Sydney Morning Herald & 3 \\
\hline
\end{tabular}

Source. Constructed by author from analysis based on content coding from selected publications (8 May to 1 July 2016 inclusive). 
The former reflects the increasing significance of the Greens as an entrenched 'third party' in Australian politics, ${ }^{10}$ while the latter a tendency for reasoning by historical analogy/historical comparator by political journalists, as well as the continuing presence of Tony Abbott on the political scene.

In the case of reported individuals and organisations, the variation within the sampled publications is less pronounced than coverage of topics and policy issues. This is because of the dominance of a small set of individuals (Turnbull, Shorten and Abbott) and organisations (the Coalition parties, ALP and Greens). However, the two youth-oriented publications, Junkee and Vice, were the least similar to the other publications in their coverage of organisations:

- Junkee committed considerable attention to the story of Duncan Storrar, an audience member on the ABCs $Q \mathcal{E} A$ show (9 May 2016) who was the subject of muckraking coverage by elements of the News Corp press following his appearance on the show (see further Carson and McNair, Chapter 19, this volume).

- Vice tended to report on different types of organisations, such as the Climate Change Authority, which received little attention from other publications.

\section{Coverage of electorates}

Overall, 28 per cent of sampled articles discussed individual electorates. While this may reflect considerable local coverage for comparatively small publications, the depth of electorate-level coverage tended to be low with many electorates simply 'name checked' against key individuals (Wentworth, for example, the prime minister's electorate) or included on lists of marginal 'seats to watch'. Because of this, as illustrated in Table 20.8, few electorates are cited frequently. Junkee and New Matilda did not report on electorates at all, while the remaining publications were quite consistent in the amount of attention given to electorates.

10 This is in terms of longevity, rather than the result of a sustained increase in primary support for the Greens from the 2007 and 2016 elections ( 9 per cent and 8.6 per cent, respectively, for the Australian Senate). 
Table 20.8. Most commonly cited electorates

\begin{tabular}{|c|c|c|c|c|c|}
\hline Rank & Electorate & $\begin{array}{c}\text { Articles } \\
\text { (percentage) }\end{array}$ & Contest & $\begin{array}{c}\text { Margin } \\
\text { (percentage) }\end{array}$ & Result \\
\hline 1 & Batman & 5.2 & ALP v Green & 10.6 & Retain \\
\hline 2 & Lindsay & 3.8 & Lib v ALP & 3.0 & ALP Gain \\
\hline 3 & New England & 3.8 & Nat $v$ Ind & 19.5 & \multirow[t]{4}{*}{ Retain } \\
\hline 4 & Grayndler & 3.6 & ALP $\vee$ Green & 18.8 & \\
\hline 5 & Wills & 3.0 & ALP v Green & 18.2 & \\
\hline 6 & Wentworth & 2.7 & Lib v ALP & 18.9 & \\
\hline 7 & Eden-Monaro & 2.5 & Lib v ALP & 2.9 & ALP Gain \\
\hline 8 & Mayo & 2.5 & Lib v NXT & 12.5 & NXT Gain \\
\hline 9 & Melbourne & 2.5 & Green v ALP & 5.3 & \multirow[t]{10}{*}{ Retain } \\
\hline 10 & Banks & 2.2 & Lib v ALP & 2.8 & \\
\hline 11 & Capricornia & 2.2 & LNP v ALP & 18.8 & \\
\hline 12 & Higgins & 2.2 & Lib v Green & 9.9 & \\
\hline 13 & Petrie & 2.2 & LNP v ALP & 0.5 & \\
\hline 14 & Brisbane & 1.9 & LNP v ALP & 4.3 & \\
\hline 15 & Dobell & 1.9 & ALP $\vee$ Lib & 0.2 & \\
\hline 16 & Indi & 1.9 & Ind v Lib & 0.3 & \\
\hline 17 & Sydney & 1.9 & ALP v Green & 12.9 & \\
\hline 18 & Warringah & 1.9 & Lib v Green & 15.3 & \\
\hline
\end{tabular}

Source. Constructed by author from analysis based on content coding from selected publications (8 May to 1 July 2016 inclusive).

Adding outcome and margin data to the table above, we cannot see a strong relationship between the significance of the contest and the likelihood an electorate would be discussed in the sample publications. Of the top 18 electorates discussed, three changed hands (17 per cent). This is higher than (but not significantly) the total proportion of electorates changing hands in 2016 (11 per cent). While this may talk to an inability to align coverage with key electorates, in many cases other news values drove reporting, such as the coverage of Batman, because of its association with the campaigning gaffes of David Feeney (as discussed in footnote 8). 


\section{Intermedia agenda setting}

One significant observation about the 2016 coverage by sampled publications was the appearance of inter-media agenda setting, metacoverage and reporting on reporting within the sample (see also Carson and McNair, Chapter 19, this volume). These types of stories/story elements involve the transmission of news agendas through the media system (often focused on the role of 'elite' media agendas on tabloid media), self-referential discussions of the role of the media within the political process and the citation of other media reports as substitutes for primary sources. They are commonly seen as problematic: a satisfied and uncritical self-absorption within the media industry and a 'churnalistic' production of new content without new substance. The latter concern also reflects the accusation of parasitism by established news organisations (Young 2011: 80), but also the way in which some news sources have become reference points for political journalists working on election newsbeats (Young 2009).

Tables 20.9 and 20.10 demonstrate the extent to which the sampled articles employed content from other media as elements in their reporting, or as the focus of the articles themselves. This is divided into two observations:

- First, direct syndication of content into the new presses from established media and news agencies. Overall, less than one in 10 articles was syndicated content, but the vast majority of this was content from the Australian Associated Press and the Australian Broadcasting Corporation (Table 20.9), and was found in the New Daily.

- Second, references to other reports or media coverage were found in one quarter of all articles in the sample, but a considerable variation existed between those publications most likely to cross-reference other publications/media organisations (New Matilda) and those least likely (BuzzFeed).

Table 20.9. Articles syndicated from other news sources or containing significant references to other publications' coverage

\begin{tabular}{|l|r|r|}
\hline Publication & $\begin{array}{r}\text { Syndicated } \\
\text { content (\%) }\end{array}$ & $\begin{array}{r}\text { References to other media } \\
\text { (\%) (excludes syndication) }\end{array}$ \\
\hline BuzzFeed Australia & 0 & 15 \\
\hline Conversation & 2 & 17 \\
\hline Guardian & 0 & 35 \\
\hline Huffington Post & $0^{*}$ & 17 \\
\hline
\end{tabular}




\begin{tabular}{|l|r|r|}
\hline Publication & $\begin{array}{r}\text { Syndicated } \\
\text { content (\%) }\end{array}$ & $\begin{array}{l}\text { References to other media } \\
\text { (\%) (excludes syndication) }\end{array}$ \\
\hline Independent Australia & 7 & 48 \\
\hline Junkee & 0 & 41 \\
\hline New Daily & 44 & 37 \\
\hline New Matilda & 0 & 50 \\
\hline Saturday Paper & 0 & 0 \\
\hline Vice Au/NZ & 0 & 20 \\
\hline All & 7 & 26 \\
\hline
\end{tabular}

* Excludes outbound links to Fairfax Media (Huffington Post partner organisation)

Source. Constructed by author from analysis based on content coding from selected publications (8 May to 1 July 2016 inclusive).

Table 20.10. Syndicated content providers

\begin{tabular}{|l|r|}
\hline Source & \% of syndicated articles \\
\hline Australian Associated Press (AAP) & 46 \\
\hline Australian Broadcasting Corporation (ABC) & 39 \\
\hline Futureproof 2016 conference & 4 \\
\hline International Consortium of Investigative Journalists & 4 \\
\hline The Conversation & 7 \\
\hline
\end{tabular}

Source. Constructed by author from analysis based on content coding from selected publications (8 May to 1 July 2016 inclusive).

Referring back to the data reported in Table 20.7, the primary media likely to be referenced (nonsyndicated) were (in descending order):

1. The $\mathrm{ABC}$ (generally), with a particular focus on events and debates on the broadcaster's popular politics panel show Q $\mho A$.

2. News Corp (generally), with particular reference to comments made by political candidates and Peta Credlin (former chief of staff to Tony Abbott) on the Sky News 24-hour news channel, and reporting in the Australian.

3. The National Press Club due to its hosting of key political debates and speeches by elites.

4. The Sydney Morning Herald newspaper.

Within the sampled articles, of the top 30 organisations cited, 50 per cent are media or polling organisations. This demonstrates the significance of polling in shaping the interpretation of electoral reporting for these 
publications, making the observations of polling quality, and agenda narrowness discussed by Murray Goot (Chapter 5, this volume) and Simon Jackman and Luke Mansillo (Chapter 6, this volume), even more important in structuring the new news.

\section{Social sharing}

The final area of substantive analysis is the extent to which sampled articles were highly rated by users on social media. To undertake this analysis, I employed the Share Tally website to determine the number of times each sampled article was 'liked' on Facebook (the market leader was used to avoid duplication associated with aggregating multiple social site data). The results are presented in Table 20.11, demonstrating an extremely high variation between sampled publications (comparative average and median figures) and between articles within publications (the high standard deviation).

The reasons for these variations need further investigation. The extent to which the tendency for articles to be liked on Facebook is neither correlated to their overall Alexa ranking (the 'halo effect'-that more popular publications would get more likes) nor on the date ('focusing event' - that more articles would get liked as the election became closer).

Table 20.11. Facebook likes for sampled articles

\begin{tabular}{|l|r|r|r|}
\hline Publication & \multicolumn{1}{|c|}{ Average } & \multicolumn{1}{c|}{ Median } & \multicolumn{1}{c|}{ St. Dev. } \\
\hline Junkee & 2,553 & 868 & 3,385 \\
\hline Guardian & 957 & 578 & 1,264 \\
\hline New Matilda & 460 & 344 & 431 \\
\hline BuzzFeed Australia & 880 & 301 & 1,573 \\
\hline Independent Australia & 173 & 106 & 204 \\
\hline Conversation & 201 & 37 & 506 \\
\hline Huffington Post & 276 & 27 & 607 \\
\hline New Daily & 12 & 2 & 40 \\
\hline Vice Au/NZ & 20 & 0 & 68 \\
\hline Saturday Paper & 6 & 0 & 15 \\
\hline All & 489 & 57 & 1,225 \\
\hline
\end{tabular}

Source. Constructed by author from analysis based on content coding from selected publications (8 May to 1 July 2016 inclusive). 


\section{Conclusion}

In 2015-16, the Coalition government twice floated proposals for another round of media deregulation. Following the long-established and bipartisan tradition of 'telegraphing' regulatory changes to incumbents, this was likely to increase the consolidation of media markets, both horizontally and vertically. One justification for this deregulatory move was the ability of the new presses to provide competition and diversity and therefore limit risks associated with exacerbating the negative impacts of the existing Australian media oligopoly (Baker, Micallef and Homewood 2015).

Based on this analysis of the performance of these new presses in the 2016 federal election, it appears their performance was mixed. The new presses are mostly small, but those with international resources have rivalled their established counterparts in reach. In many areas, however, the new presses with the largest reach appear to mirror the types of reporting approaches and styles of established media actors. The focus on political topics, actors and organisations appears quite narrow, following Goot's (2008) observations from a decade earlier. Contrary to the hopes of writers like Jim Macnamara (2014), these presses have not (yet) brought considerable innovation to journalistic practices.

Then again, the new presses have proven diverse in what they produce and who they target as their readership. In quality terms, a number of these presses have different editorial foci more akin to news magazines than newspapers, and some are working hard to form relations with underserviced audiences (particularly young people) through innovation in the presentation of content, but also in the reporting of issues outside of the mainstream. Outside of The Conversation's use of the university sector for information subsidies, the majority of these new presses remain limited by a political economy that has not yet found an effective commercial model to scale these publications. This drives 'churnalism' and metacoverage in some areas and extends the tendency of 'dumping' content from media organisations' home markets into their Australian properties. With the arrival of the Daily Mail Australia (2014), and anticipated launch of a localised New York Times (Lichterman 2016), this is likely to be a deepening tendency. 


\section{References}

Australian Collaboration. 2015. Democracy in Australia - Media Concentration and Media Laws. Albert Park, VIC: Australian Collaboration.

Baker, Rosy, Rachel Micallef and Sarah Homewood. 2015. 'PwC: There is no hurdle to media reform now Turnbull is PM'. AdNews, 15 September. Available at: www.adnews.com.au/news/pwc-there-isno-hurdle-to-media-reform-now-turnbull-is-pm

Baum, Matthew. 2011. Soft News Goes to War: Public Opinion and American Foreign Policy in the New Media Age. Princeton: Princeton University Press.

Bennett, W. Lance. 2012. News: The Politics of Illusion. 9th edition. Chicago: University of Chicago Press.

Essential Media Communications. 2016. Most Important Election Issues. 1 March. Available at: www.essentialvision.com.au/most-importantelection-issues-5

Goot, Murray. 2008. 'Is the news on the internet different? Leaders, frontbenchers and other candidates in the 2007 Australian election'. Australian Journal of Political Science 43(1): 99-110. doi.org/10.1080/ 10361140701851939

Gray, Jonathan, Lucy Chambers and Liliana Bounegru. 2012. The Data Journalism Handbook: How Journalists Can Use Data to Improve the News. Sebastopol: O’Reilly Media.

Kamerer, David. 2013. 'Estimating online audiences: Understanding the limitations of competitive intelligence services'. First Monday 18(5-6). doi.org/10.5210/fm.v18i5.3986

Krum, Randy. 2014. Cool Infographics: Effective Communication with Data Visualization and Design. Indianapolis: John Wiley \& Sons.

Lester, Libby, Lyn McGaurr and Bruce Tranter. 2015. 'The election that forgot the environment? Issues, EMOs, and the press in Australia'. The International Journal of Press/Politics 20(1): 3-25. doi.org/10.1177/ 1940161214552030 
Lichterman, Joseph. 2016. 'Report: The New York Times is expanding to Australia and Canada'. NiemanLab, 23 August. Available at: www. niemanlab.org/2016/08/report-the-new-york-times-is-expanding-toaustralia-and-canada/

Macnamara, Jim. 2014. The 21st Century Media (R)evolution. 2nd edition. New York: Peter Lang.

Robin, Myriam. 2014. 'Move over, BuzzFeed: How Junkee is making its own way (and making money) online'. Crikey, 26 March. Available at: www.crikey.com.au/2014/03/26/move-over-BuzzFeed-how-junkeeis-making-its-own-way-and-making-money-online/

Roy Morgan Research. 2014. 'The Australian's website audience is more similar to the Guardian's than its own print edition'. 28 May. Available at: www.roymorgan.com/findings/5607-news-website-helix-audienceprofiles-march-2014-201405280459

Winseck, Dwayne. 2008. 'The state of media ownership and media markets: competition or concentration and why should we care?' Sociology Compass 2(1): 34-47. doi.org/10.1111/j.1751-9020.2007.00061.x

Young, Sally. 2009. 'Sky News Australia'. Journalism Studies 10(3): 401-16. doi.org/10.1080/14616700802636250

—_. 2011. How Australia Decides: Election Reporting and the Media. Cambridge: Cambridge University Press. 
This text is taken from Double Disillusion: The 2016 Australian Federal Election, edited by Anika Gauja, Peter Chen, Jennifer Curtin and Juliet Pietsch, published 2018 by ANU Press, The Australian

National University, Canberra, Australia.

doi.org/10.22459/DD.04.2018.20 